These letters are indeed pages of the history of the very origins of the Red Cross in its traditional relief role.

Another fine exhibit was a letter-card bearing the Red Cross emblems and dated 13 August 1870 with the heading of the St-Louis Committee (Upper Rhine, France) of the International Society of Relief for Wounded Soldiers, with the following text: "This Committee puts itself at your entire disposal for the letters you may have to send to Germany or receive from that country ".

The other frames offered a veritable world tour through envelopes, cards, cancellations, postage stamps and seals, most of which were rarities.

There was a magnificent series of "visiting envelopes" of the Russian Red Cross for the period 1878-1903, an exceptional set of precursors of the " charity" stamps of the Ottoman Red Crescent between 1910 and 1916, Red Cross stamps and seals on letters through the years, right up to the issues in tribute to the Red Cross Centenary, celebrated the world over in 1963.

\title{
League of Red Cross Societies Report
}

The League's Annual Report for 1966 covers its activities under the following headings: Development Programme; Relief, Health and Social Service; Nursing; Youth; Public Relations; and International Relations. It is concluded by financial statements.

In his introduction, Mr. H. Beer, Secretary-General, draws attention to some major problems: "With the growing universality of the Red Cross, the League is faced with constantly increasing responsibilities. Since the XXth International Conference of the Red Cross, (Vienna, October 1965), the League's activities have vastly developed, while the economic and technical difficulties with which it has had to contend during the past months have shown no signs of diminishing.

Two essential and closely interdependent activities have headed the list of priorities, both calling for the utmost degree of attention 


\section{IN THE Red Cross WorLd}

on the part of the League: disaster relief and development problems.

It has become manifest that if the League is to adequately play its rôle as principal international relief organization, the development of the National Societies in disaster-prone countries must be an absolute priority involving a new orientation in the work of the League. The League is studying, in accordance with the directions of the XXth International Conference, the ways and means whereby National Societies can best arm themselves against the effects of the disasters and assist the authorities in meeting the needs of the victims.

Despite the lack of economic resources and the scarcity of qualified personnel, the Red Cross Development Programme of the League has come into its own in 1966: the number of regional delegates has been increased and the organization of regional seminars intensified."

Tables included in the report show how essential the Development Programme has become for the establishing of National Societies in newly independent countries. They also show how the League has intervened on every continent after natural disasters or in other emergencies. To quote but one example, 36 National Societies took part in the action undertaken in India, where famine was raging, by sending relief supplies which reached a value of over Fr. 19 million by the end of 1966. 